\title{
Gold and colloidal gold surface influence on DNA conformational change
}

\author{
G.I. Dovbeshko' ${ }^{1}$ O.P. Gnatyuk ${ }^{1}$, V.I. Chegel ${ }^{2}$, Y.M. Shirshov ${ }^{2}$, D.V. Kosenkov' ${ }^{1}$, \\ E.A. Andreev' ${ }^{1}$ H.A. Tajmir-Riahi ${ }^{3}$, P.M. Lytvyn ${ }^{2}$ \\ ${ }^{1}$ Institute of Physics, NAS of Ukraine, 46, prospect Nauky, 03028 Kyiv, Ukraine \\ Phone: +380(44)2659851,E-mail: gd@iop.kiev.ua \\ ${ }^{2} V$. Lashkaryov Institute of Semiconductor Physics, NAS of Ukraine, 41, prospect Nauky, 03028 Kyiv, Ukraine \\ ${ }^{3}$ Department of Chemistry-Biology, University of Quebec at Trois-Rivieres, C.P. 500 TR (Quebec) Canada G9A 5H7
}

\begin{abstract}
DNA conformational changes caused by gold and colloidal gold surface have been studied by surface enhanced infrared spectroscopy (SEIRA), spectroscopy of plasmon resonance (SPR), atomic force microscopy (AFM) and principal component analysis. Experimental data have shown that DNA conformation is slightly influenced by gold surface, while it is strongly altered by colloidal gold. Spectroscopic features of DNA-colloidal gold system have shown that the intensity of the asymmetric $\mathrm{PO}_{2}^{-}$band at $1240 \mathrm{~cm}^{-1}$ decreases by two times, and that of symmetric band at $1090 \mathrm{~cm}^{-1}$ decreases by 2.4 times whereas the halfwidth of phosphate bands increases by $35-40 \mathrm{~cm}^{-1}$; a frequency shift of asymmetric band position from 1240 to $1246 \mathrm{~cm}^{-1}$ and a symmetric band from 1090 to $1106 \mathrm{~cm}^{-1}$ has been observed. It was shown that intensity variation and shift of DNA base vibrations together with the broadening of $\mathrm{OH}, \mathrm{NH}$, and $\mathrm{CH}$ stretching vibrations occur due to DNA conformational changes and the redistribution of the H-bonding network. A supposition about DNA condensation by colloidal gold was made. SEIRA and AFM data have showed major DNA structural changes occurred on gold colloidal particles. It was found that all the spectral features are more prominent for DNA-colloidal gold system deposited on gold substrate than on $\mathrm{CaF}_{2}$ substrate.
\end{abstract}

Keywords: DNA conformation, Surface Enhanced Infrared Absorption (SEIRA) spectroscopy, gold, colloidal gold, AFM (atomic force microscopy), SPR (spectroscopy of plasmon resonance).

Paper received 07.05.04; accepted for publication 21.10.04.

\section{Introduction}

In modern technology, gold and colloidal gold are used for immobilization of biological molecules, such as DNA and/or protein on their surfaces [1-3]. Gold surface is widely used for effective enhancement of optical signal in luminescence [4], Raman scattering [5, 6] and infrared (IR) absorption [7, 8] of different molecules. Here special attention is paid to nucleic acids and proteins, due to the fact that any substrate could influence the conformations of these complex molecules after their precipitation from the solution [9].

FTIR (Fourie Transform Infra-Red) spectroscopy methods are essential for structural studies of the biological molecules and their conformations, because of their increased sensitivity (i.e. signal/noise ratio). However, in biochemical applications where very small amounts of materials are available, modern FTIR alone often can not provide sufficient sensitivity. Isolation and purification of nucleic acids require time and materials, so any technique capable of enhancing the FTIR signal is very important for analytical methods. Earlier, we registered an enhancement ( 3 to 5 times) of the FTIR signal in reflectance modes for DNA on gold rough substrate [10, 11]. More drastic enhancement of IR signal (18.5 times) of membrane with metal particles in attenuated total reflection mode was reported [12]. The method of enhanced infrared absorption by metal surface is named in literature as SEIRA (surface enhanced infrared absorption) similar to well-known SERS (Surface Enhanced Raman Scattering). The mechanism of this effect has been theoretically studied by Kosobukin in 1983 [8] and consists of two different processes: a) the local enhancement of external electric field near rough metal surface, due to excitation of local or surface plasmon and b) the specific increase of the molecules polarizability at their adsorption on metal surface. 


\section{G.I. Dovbeshko et al.: Gold and colloidal gold surface influence on DNA conformational changes}

On the other hand, SPR (surface of plasmon resonance) technique is a sensitive tool for characterisation of dielectric properties of thin layers. So, it could be used to study the structure of colloidal gold-DNA system.

In this paper, we present data on the conformational state of DNA on gold and colloidal gold surfaces studied by SEIRA, SPR, atomic force microscopy (AFM) and statistic methods.

\section{Experimental}

\subsection{SEIRA spectroscopy and spectral evaluation}

SEIRA spectra were collected with IFS-48 Bruker instrument in IR reflectance mode for the DNA on gold substrate. The reflectance attachment used in the experiment has the light incidence angle close to $16.5^{\circ}$ [11]. We used Au of $200-500 \AA$ thickness on glass plate as a metal substrate. Spectra of DNA with colloidal gold on $\mathrm{CaF}_{2}$ substrate were collected in the transmittance mode. Evaluation of the spectra was done with Opus 2.2 soft-wear. The position of the bands was estimated using the method of the second derivative and/or standard method. The band intensity was normalized with respect to the maximal intensity of $\mathrm{OH}, \mathrm{NH}$, or $\mathrm{CH}$ stretching vibration in the region of $3340-3400 \mathrm{~cm}^{-1}$.

These vibrations were assigned to the certain functional groups in DNA [13-18]. To estimate the halfwidth, the intensity and the real frequencies of overlapping bands, the complex spectral bands, in the regions of 3800 $2300 \mathrm{~cm}^{-1}$ (region of the $\mathrm{OH}, \mathrm{NH}$, and $\mathrm{CH}$ stretching vibrations), $1800-1300 \mathrm{~cm}^{-1}$ (region of $\mathrm{C}=\mathrm{O}, \mathrm{C}=\mathrm{C}, \mathrm{C}=\mathrm{N}$ stretching, $\mathrm{C}-\mathrm{H}$ and $\mathrm{N}-\mathrm{H}$ deformation modes) and 1300 $1000 \mathrm{~cm}^{-1}$ (region of $\mathrm{PO}_{2}^{-}$vibrations) were decomposed with the option "Curve fit" of Opus 2.2. Shapes of different spectral bands under decomposition were approximated with a sum of Lorenzian or Gaussian functions. The spectra were normalized to:

i) peak intensity of $\mathrm{OH}$ vibrations (the most strong line in the spectra) for estimating the band parameters, in the $4000-700 \mathrm{~cm}^{-1}$ region;

ii) peak intensity of base vibration at $1650 \mathrm{~cm}^{-1}$ for estimating the band intensity, in the $1800-700 \mathrm{~cm}^{-1}$ region.

Accuracy of frequency and absorption determination in the SEIRA spectra were to $\pm 0.5 \mathrm{~cm}^{-1}$ and \pm 0.0005 a.u., respectively.

Thr principal component analysis was applied for SEIRA spectral evaluation. One principal component was the relative intensity of the phosphate asymmetric band (at $1240 \mathrm{~cm}^{-1}$ ) to maximum intensity at $3400-2300 \mathrm{~cm}^{-1}$ (OH stretching vibrations). This component multiplied by 5.25 characterises the number of water molecules per nucleotide [19]. The second principal component was the ratio of intensities at $1712 \mathrm{~cm}^{-1}$ and at $1700 \mathrm{~cm}^{-1}$, marker bands for DNA conformations in A, B or Z-form. Earlier, we estimated the contribution of the above mentioned components and found that they show a preferential contribution [20].

\subsection{Preparation of DNA with colloidal gold}

Colloidal gold nanoparticles of $10-15 \mathrm{~nm}$ size (produced by reduction of $\mathrm{Au}$ from $\mathrm{HAuCl}_{4}$ with citrate of $12.1 \mathrm{~g} / \mathrm{l}$ concentration ) were mixed with aqueous solution of sodium salt calf-thymus DNA (highly polymerised from Servo) $\left(5 \times 10^{-3} \mathrm{M}\right)$ and kept 24 hours in a refrigerator. Then, it was precipitated on gold substrate as well as on $\mathrm{CaF}_{2}$ and dried at room temperature with a vacuum fen. We prepared the DNA samples with different amounts of colloidal gold (1, 2 and 3 drops of colloidal gold per $10 \mu \mathrm{l}$ DNA solution). A drop is about $10 \mu \mathrm{l}$. The same DNA aqueous solution without colloidal gold was used for reference DNA.

\subsection{AFM imaging}

The microphotographs of the Au surface, used as substrate for SEIRA, the colloidal particles on gold substrate and the DNA with colloidal particles on gold substrate were obtained by atomic force microscopy (AFM). We used the tapping mode under AFM imaging, with a commercial Nanoscope IIIa (Digital Instrument, Santa Barbara, CA). Tapping force mode scans were performed using commercially available AFM tips (silicon nitride). The scanning frequency was approximately $1 \mathrm{~Hz}$ in all the experiments.

\subsection{SPR experimental set}

Gold thin layer for DNA adsorption and SPR measurement were obtained by vacuum deposition of 99.999 pure Au upon glass supports (TF-1 glass, $20 \times 20 \mathrm{~mm}$ ), via an intermediate adhesive $\mathrm{Cr}$ layer. Before $\mathrm{Au}$ deposition, the glass surface was cleaned by $\mathrm{NH}_{4} \mathrm{OH}: \mathrm{H}_{2} \mathrm{O}_{2}: \mathrm{H}_{2} \mathrm{O}$ and $\mathrm{HCl}: \mathrm{H}_{2} \mathrm{O}_{2}: \mathrm{H}_{2} \mathrm{O}$ solution subsequently, both $1: 2: 2$ by volume concentration during 5 minutes at boiling temperature. Then, it was rinsed in double distilled water and dried in a flow of pure nitrogen. Gold was evaporated from a molybdenum heater and deposited at a rate of $1.0-1.5 \mathrm{~nm} \cdot \mathrm{s}^{-1}$ on the room temperature substrate. The thickness of gold surface was within 200-500 $\AA$ in different experiments, and for SPR we used gold with $500 \AA$ thickness. The Cr interlayer did not exceed 30-50 A. The gold surface just after deposition looks like hydrophobic surface with wetting angle close to $80^{\circ}$ and random roughness of about $50 \AA$ (Fig. 1).

The commercially available SPR Kretschmann-type spectrometer (Biosuplar-2, Analytical $\mu$-System, Germany) with a light-emitting diode as the light source, $\lambda=6700 \AA$, was used for these SPR measurements. A high reflection index of the prism $(n=1.61)$ and a broad dynamic range (up to $19^{\circ}$ in air) of the SPR instrument gives a possibility for analysis of modified surface without changes of the initial angle. 


\section{G.I. Dovbeshko et al.: Gold and colloidal gold surface influence on DNA conformational changes}

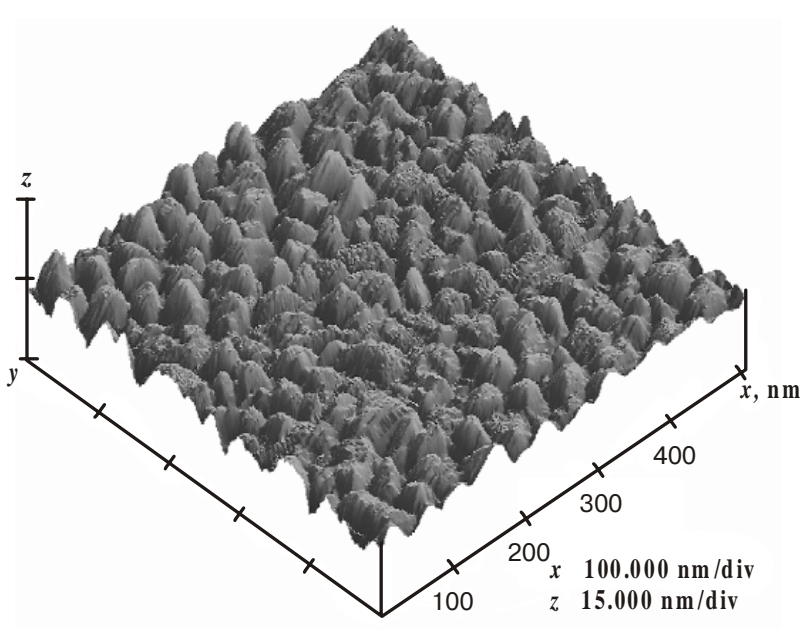

Fig. 1. Image of gold surface used in SEIRA and SPR experiments.

\subsection{Peculiarities of DNA structure in $A$ and $B$ - form precipitated on gold substrate in SEIRA experiments}

The DNA right-handed helix blocks adopts the $C_{3^{\prime}}$-endo/ anti sugar-base conformation in the $\mathrm{A}$ form and $C_{2^{\prime}}$-endo/ anti in the B form [21]. The marker bands are $890 \mathrm{~cm}^{-1}$, $878 \mathrm{~cm}^{-1}, 860 \mathrm{~cm}^{-1}$ and $805 \mathrm{~cm}^{-1}$ for the $C_{3^{\prime}}$-endo/anti (A-form helix) conformation, as well as $890 \mathrm{~cm}^{-1}$ and $835 \mathrm{~cm}^{-1}$ for the $C_{2^{\prime}}$-endo/anti (B-form helix) conformation [13, 14] (Table 1). In the left-handed helix DNA (Zform) the positions of the IR bands are $925-929 \mathrm{~cm}^{-1}$, $868 \mathrm{~cm}^{-1}, 835-840 \mathrm{~cm}^{-1}$ and $802-805 \mathrm{~cm}^{-1}$ in the $C_{3^{\prime}}$, endo/syn and $C_{2}$-endo/anti sugar-base geometry [13, 16]. A strong guanine/thymine IR band appears at 1712 $1717 \mathrm{~cm}^{-1}$ (B-form), $1700 \mathrm{~cm}^{-1}$ (A-form) and $1690 \mathrm{~cm}^{-1}$ (Z-form) $[14,15]$. Similarly, the asymmetric $\mathrm{PO}_{2}$ band appears at $1222 \mathrm{~cm}^{-1}$ (B-form), 1240 (A-form) and 1216 $1218 \mathrm{~cm}^{-1}$ (Z-form) [14, 15].

It is well known that humidity plays a major role in DNA conformations and the backbone $\mathrm{PO}_{2}$ asymmetric vibration at $1222 \mathrm{~cm}^{-1}$ is sensitive to DNA conformational transition [14, 22-24]. We repeatedly tested the humidity of the sample (20 times per hour), and recorded IR spectra for the following days. In all our experiments, the humidity was $60 \%$, and we recorded reproducible spectra. However, for Na-DNA (calf thymus) on the gold substrate we observed the marker bands in the sugar region at the following frequencies: strong $928 \mathrm{~cm}^{-1}$ (Zform), strong $890 \mathrm{~cm}^{-1}$ (both A and B-forms), $859 \mathrm{~cm}^{-1}$ (A-form) and strong $832 \mathrm{~cm}^{-1}$ (B-form or Z-form) (Table 1). If we estimate the contribution of $A$ and $B$ forms according to Taillandier et al., 1985, we find some presence of the B-form. This seems impossible in our experimental conditions of $60 \%$ humidity, where a disordered (coil) structure could be expected with a much greater contribution from the A-helix form. The majority of the spectral markers for Na-DNA on the gold substrate are close to the markers of A-form [16]. The data presented are 1092 (1095), 1240 (1240), 1277 (1275), 1370 (1375), 1419 (1418), 1701 (1705) $\mathrm{cm}^{-1}$ (Table 1). For B-form DNA on gold (prepared by us with $90-100 \%$ humidity), the positions are close to common markers of B-form (Schrader, 1995) namely, 1088 (1085), 1222 (1220-1225), 1281 (1281), 1374 (1374-1375), 1425 (1425-1430), 1715 (1714-1718) $\mathrm{cm}^{-1}$ (Table 1).

We must assume that any substrate can strongly influence the sugar conformation of DNA, even in the case when other structural components are not perturbed. Therefore, the influence of substrate on DNA spectra should be estimated separately, in every case. In our case, we observed that the gold substrate induces conformational changes of the sugars, if they come closely to gold surface. The band observed at $832 \mathrm{~cm}^{-1}$ is presumably due to reformation of intermolecular $\mathrm{H}$-bonding $(\mathrm{NH}$, $\mathrm{OH}$ and $\mathrm{CH}$ groups) near to the gold substrate [22], as the result of DNA bending at gold peaks. It is also possible that water molecules take active part in this process.

A similar process was reported earlier [25] in connection with non-coincidence of the data obtained with inelastic scattering of nucleic acid blocks in solid state and calculations with the density functional theory for the spectral region under $900 \mathrm{~cm}^{-1}$. It has been shown that intermolecular $\mathrm{H}$-bonds were formed in the film involving $\mathrm{N}_{1}-\mathrm{H}$ and $\mathrm{N}_{3}-\mathrm{H}$ groups of the bases, giving a strong band at $830 \mathrm{~cm}^{-1}$. In our case, the bands at $834 \mathrm{~cm}^{-1}$ and $832 \mathrm{~cm}^{-1}$ in B and A forms of DNA on gold were registered, respectively.

It is very difficult to resolve peaks at 1054 and $1070 \mathrm{~cm}^{-1}$ (deoxyribose $\mathrm{C}-\mathrm{O}$ vibrations), as well as 1153 and $1019 \mathrm{~cm}^{-1}$ vibrations $\left(C_{2^{\prime}}-\mathrm{O}\right)$ for DNA on a transparent substrate. In DNA on gold substrate, we could separate some of these vibrations due to the changes in nucleic acid structure under internal or external stimuli [26].

We should mention that the band intensity dependence on concentration and thickness of the films was not observed for nucleic acids within $10^{-2}$ to $10^{-4} \mathrm{M}$ concentration range.

\subsection{DNA-colloidal gold system on gold and $\mathrm{CaF}_{2}$ substrate}

Surface of the gold film on $\mathrm{SiO}_{2}$ and colloidal gold on $\mathrm{Au} / \mathrm{SiO}_{2}$ has some differences (Fig. 2): the size of particles of colloidal gold (15-4000 $)$ is larger than for the roughness of Au-surface and they have non-homogenous distribution.

In DNA-colloidal gold system on gold substrate the main spectral features are as follows (Figs 3, 4):

i) 2,4 time decrease in the intensity of the phosphate bands at $1104 \mathrm{~cm}^{-1}$ (symmetric stretch) and two-fold decrease at $1240 \mathrm{~cm}^{-1}$ (asymmetric stretch);

ii) 1.3 time decrease in the intensity of the base bands at $1800-1550 \mathrm{~cm}^{-1}$ (1.3-folds). However, the relative intensity of the base band to the phosphate one is increased by 1.6 time for asymmetric $\mathrm{PO}_{2}$ and 1.8 time for symmetric $\mathrm{PO}_{2}$ vibrations. 


\section{G.I. Dovbeshko et al.: Gold and colloidal gold surface influence on DNA conformational changes}

Table 1. Frequencies of vibration bands for DNA in different conformational states.

\begin{tabular}{|c|c|c|c|}
\hline \multicolumn{3}{|c|}{ DNA Conformation } & \multirow[t]{2}{*}{ Assignment } \\
\hline A-form & B-form & Z-form & \\
\hline $\begin{array}{l}1700-1709 \\
{[14-16,38]}\end{array}$ & $\begin{array}{l}1714-1718 \\
{[14-16,38]}\end{array}$ & $\begin{array}{l}1690-1700 \\
{[15]}\end{array}$ & $\mathrm{C}=\mathrm{O}$ thymine, guanine \\
\hline $1620[29]$ & $1620[29]$ & $1630[14]$ & $\mathrm{C}=\mathrm{N}$ adenine, guanine \\
\hline $1575[29]$ & 1575 [29] & & $\mathrm{C}=\mathrm{N}$ guanine \\
\hline $1527-1529[15]$ & $\begin{array}{l}1527-1529[15] \\
1492[15]\end{array}$ & $\begin{array}{l}1529-1533[15] \\
1485-1490[15] \\
1434[16]\end{array}$ & $\begin{array}{l}\text { Cytosine } \\
\text { Guanine, cytosine } \\
\text { A-T pairs }\end{array}$ \\
\hline $\begin{array}{l}1418-1421 \\
{[14,16,38]}\end{array}$ & $\begin{array}{l}1425-1430 \\
{[14,16,38]}\end{array}$ & $\begin{array}{l}1408-1412 \\
{[16,38]}\end{array}$ & $\begin{array}{l}\text { Def. C-H deoxyribose, } \\
\text { Def. N-H, str. C-N }\end{array}$ \\
\hline $\begin{array}{l}1374 \\
{[38]}\end{array}$ & $\begin{array}{l}1374-1375 \\
{[14,16]}\end{array}$ & $\begin{array}{l}1354-1357 \\
{[14,16,38]}\end{array}$ & Str. $\mathrm{C}-\mathrm{N}$ adenine, guanine \\
\hline \multirow[t]{2}{*}{$1331-1335[38]$} & $1342-1344[38]$ & & Str. C-N thymine, adenine \\
\hline & & $\begin{array}{l}1318-1320 \\
{[14,16,38]}\end{array}$ & Guanine, cytosine \\
\hline \multirow[t]{2}{*}{$1274-1277[38]$} & $1281[38]$ & & $\mathrm{N}-\mathrm{H}$ thymine, \\
\hline & & $\begin{array}{l}1264-1265 \\
{[14,16,38]}\end{array}$ & Cytosine, guanine \\
\hline $\begin{array}{l}1234-1240 \\
{[14,16,38]}\end{array}$ & $\begin{array}{l}1220-1225 \\
{[14,16,38]}\end{array}$ & $\begin{array}{l}1215-1218 \\
{[14,16,38]}\end{array}$ & Str. $\mathrm{PO}_{2}^{-}$antisym. \\
\hline \multirow[t]{2}{*}{$\begin{array}{l}1189-1185 \\
{[16,38,39]}\end{array}$} & & & $\mathrm{C}-\mathrm{C}$ deoxyribose \\
\hline & & $1124[14]$ & $\mathrm{C}-\mathrm{O}-\mathrm{C}$ ring deoxyribose \\
\hline $1090[14]$ & $1085[14]$ & & Str. $\mathrm{PO}_{2}^{-}$sym. \\
\hline \multirow[t]{2}{*}{$1052-1053[40]$} & $1055[24]$ & $1060-1065[16,38]$ & Str. C-O deoxyribose \\
\hline & & 1013-1018 [14, 16] & $\mathrm{C}-\mathrm{O}-\mathrm{C}$ ring deoxyribose \\
\hline \multirow[t]{3}{*}{$968-972[38]$} & 967-969[38, 40] & & $\mathrm{C}-\mathrm{O}-\mathrm{C}$ ring deoxyribose \\
\hline & $936-938[38]$ & & Deoxyribose \\
\hline & & $\begin{array}{l}925-929 \\
{[14,16,38,]}\end{array}$ & $\mathrm{C}-\mathrm{O}-\mathrm{C}$ ring deoxyribose \\
\hline $895-899$ [38] & $892-896$ [38] & & \\
\hline \multicolumn{4}{|l|}{$879-885$ [38] } \\
\hline \multirow[t]{2}{*}{$860-864[14,38]$} & & $864-868[38]$ & $C_{3^{\prime}}$-endo deoxyribose \\
\hline & $841-835[14,38]$ & $834-840[38]$ & $C_{2^{\prime}}-$ endo deoxyribose \\
\hline $805-808[14,38]$ & & & $C_{3^{\prime}}$-endo deoxyribose \\
\hline \multirow[t]{2}{*}{$795[14]$} & & & Adenine \\
\hline & & $778-784[14]$ & Guanine (-syn-form) \\
\hline $778[14]$ & & & Guanine, cytosine \\
\hline $764[14]$ & & & Thymine \\
\hline
\end{tabular}

Str., stretching; def., deformation; sym., symmetric; asym., asymmetric.

iii) widening the halfwidth of phosphate bands up to 35 $40 \mathrm{~cm}^{-1}$ for asymmetric phosphate;

iv) high frequency shift of asymmetric phosphate from 1240 to $1244 \mathrm{~cm}^{-1}$, appearance of shoulder at 1222 $1215 \mathrm{~cm}^{-1}$;

v) high frequency shift of symmetric phosphate from 1093 to $1104 \mathrm{~cm}^{-1}$;

$S Q O, 7(3), 2004$ vi) decrease of shoulder band of symmetric phosphate at $1050-1070 \mathrm{~cm}^{-1}$;

vii) widening the halfwidth of $\mathrm{OH}$ and $\mathrm{NH}$ stretching bands up to $250 \mathrm{~cm}^{-1}$ and their high frequency shift of about $100 \mathrm{~cm}^{-1}$.

DNA with colloidal gold has features that are none A, B or Z-form. However, canonical forms of DNA are 


\section{G.I. Dovbeshko et al.: Gold and colloidal gold surface influence on DNA conformational changes}
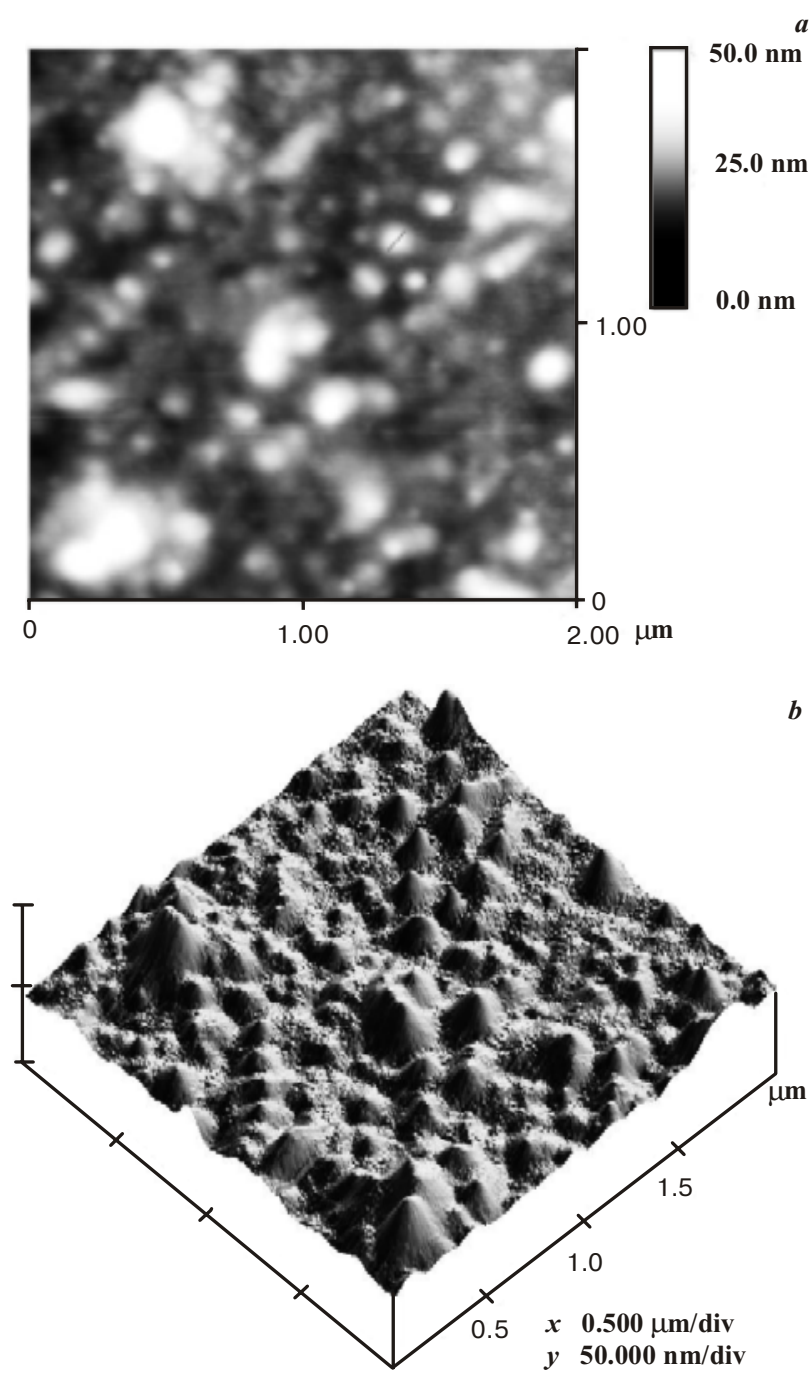

Fig. 2. 2-D (a) and 3-D (b) AFM images of colloidal gold on $\mathrm{Au} / \mathrm{SiO}_{2}$ substrate.

also present here, especially $\mathrm{B}$ and $\mathrm{Z}$-forms $\left(930 \mathrm{~cm}^{-1}\right)$ and reduction of A-form $\left(860 \mathrm{~cm}^{-1}\right)$. The intensity of the band at $960 \mathrm{~cm}^{-1}$ decreased about 1.5 to 2 -fold.

We should add that all the spectral features for DNAcolloidal gold are most prominent on the gold substrate (Fig. 3, curve $a, b$; Fig. 4, curve 3), in comparison with those on $\mathrm{CaF}_{2}$ (Fig. 3, curve $c, d$ ). We suppose that the spectral features of DNA show the process of condensation due to the fact that relative phosphate and base intensity of DNA-colloidal gold looks like those in condensed DNA. Really, Max Diem et al. [27, 28] have observed the spectroscopic feature of the process of DNA condensation in nuclei of living single cell, namely, a decrease of phosphate bands in the case of the inactive cell phase. The spectroscopic features of DNA condensation were observed by Blagoi and Kornilova [29], in a study of DNA interaction with polycations. The characteristic features were an increase of the base band intensity near $1650 \mathrm{~cm}^{-1}$ and a decrease of the intensity of the phosphate band in DNA- $\mathrm{Mn}^{2+}$ complexes [29].
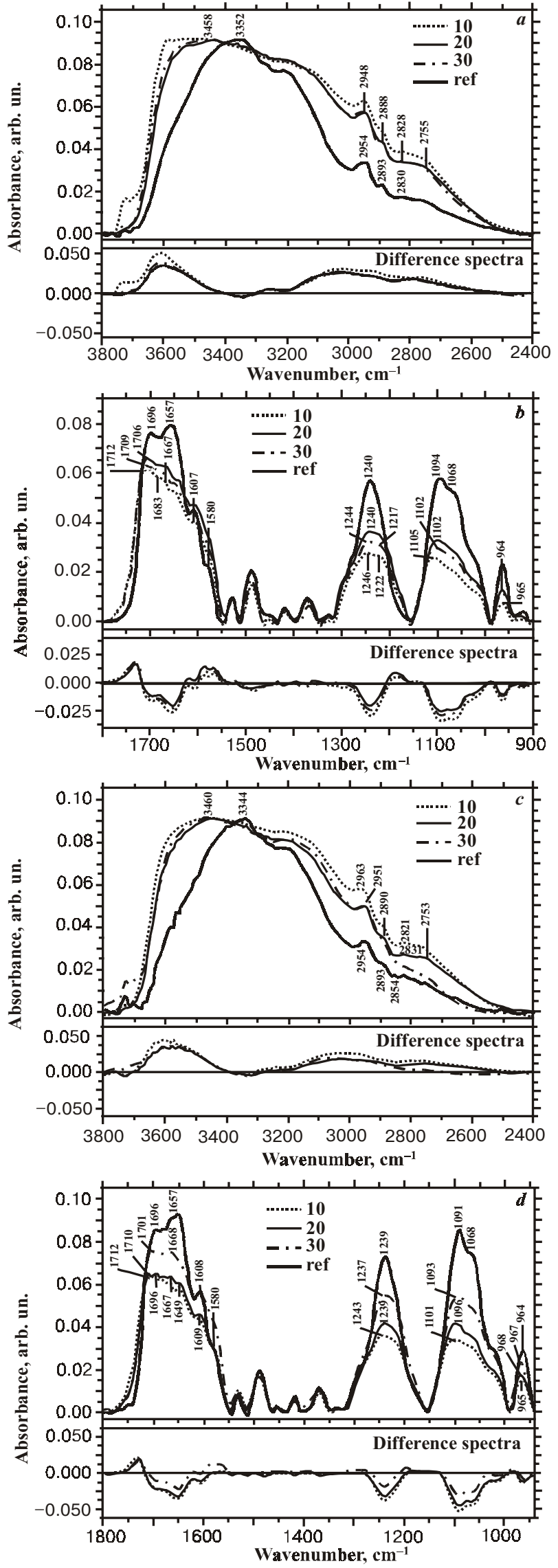

Fig. 3. The SEIRA spectra of DNA-colloidal gold system on a), b) Au substrate and c), d) $\mathrm{CaF}_{2}$ substrate.

SQO, 7(3), 2004 


\section{G.I. Dovbeshko et al.: Gold and colloidal gold surface influence on DNA conformational changes}

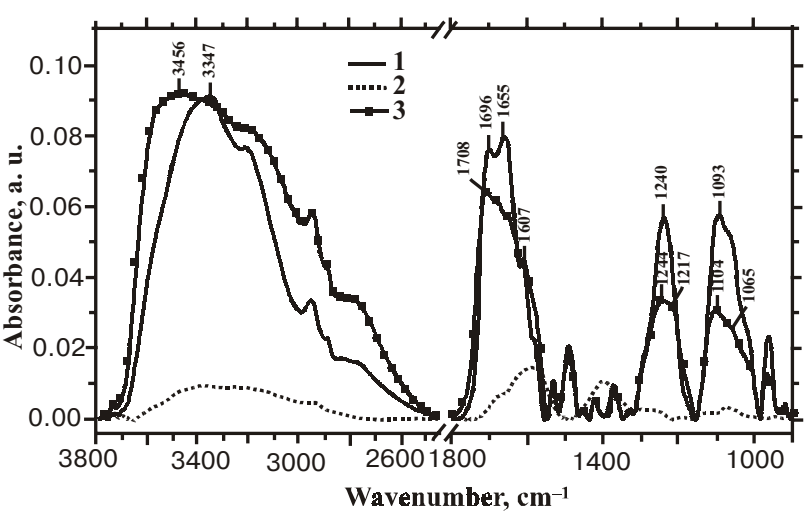

Fig. 4. SEIRA spectra of the DNA - colloidal gold system: 1 reference DNA on Au substrate, 2 - colloidal gold on Au substrate, 3 - DNA-colloidal gold system on gold substrate.

We have also observed the spectral features of DNA aggregation. Aggregation occurred without adding of metal ions, but condensation did not occur. As usual, in the case of aggregation no decrease of the phosphate band intensity is observed. Our principal component analysis in the modified form (described in section 2.1) was applied for the conversion of the different spectra in separate points. Such presentation (Fig. 5) shows that the points corresponded to canonical DNA (A and B form) or condensed DNA (Au10, Au20, Au30) have different region of localization in the principal component plane. In this plane, the DNA-colloidal gold is close to B-form, however, our experimental condition induces A-form.

By using microscopy, it is possible to prove a process of condensation (the formation of finite size and orderly morphology structures). In the AFM image (Fig. 6), the elongated ordering structure of DNA fibers of white colour (Fig. 6b) could be seen. We suppose that DNA have been condensed, aligned and organised in numerous rods.

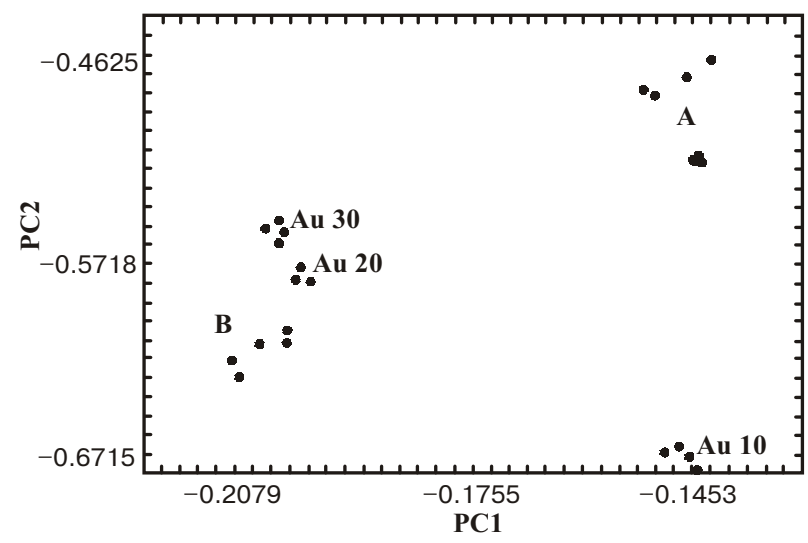

Fig. 5. Principal component analysis of DNA of A, B DNA canonical forms assigned by $\mathrm{A}, \mathrm{B}$ accordingly and DNA condensed by different amounts of colloidal gold $(10,20$ and $30 \mu \mathrm{l}$ per $10 \mu \mathrm{l}$ DNA of $5 \cdot 10^{-3} \mathrm{M}$, assigned to Au10, Au20, Au30 accordingly).

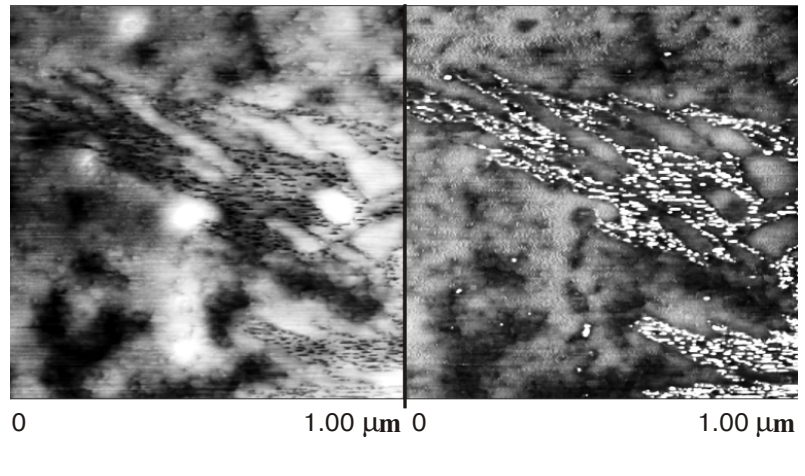

Fig. 6. AFM images of DNA with colloidal gold: $a-2-\mathrm{D}$ image of DNA condensed by colloidal gold, $b-2$-D image of the same sample with an other contrast.

The length of these ordered structures is about tenth parts of microns. So, some features of the condensation process seem to become visible in our AMF picture for DNA with colloidal gold (Fig. $6 a, b$ ).

The process of DNA-colloidal gold interaction has been studied with SPR, by comparing the adsorption of the colloidal gold and its mixture with DNA on gold surface. In Fig. 7, the kinetics of adsorption of the colloidal gold aqueous solution with different concentrations is shown (Fig. $7 a, b$, curve 1). The kinetics of adsorption for the mixture of DNA-colloidal gold are also presented Fig. $7 a, b$, curve 2 . The high concentration of colloidal gold revealed the essential difference in SPR response, in contrast to a small colloidal gold concentration. The SPR spectra show drastic changes in their positions and halfwidth in the case of colloidal gold particles adsorbed on gold surface in comparison with bare gold (Fig. 8a).

It should be noted that for small concentrations of colloidal gold the difference in SPR response is less evident (Fig. 7b). The drastic decrease of the SPR response for DNA-colloidal gold system (high concentration) shows only slight change in SPR position (Fig. 8b).

The observed differences in the SPR response reveal that DNA colloidal gold causes a drastic decrease of the effective refraction index of the adsorbed layer. We concluded that the SPR response is a result of DNA conformational changes in this case. This could be explained by the formation of clusters DNA-colloidal gold as a result of the possible condensation processes. A similar decrease in the SPR response was observed for Ag clusters, in the polymer matrix [27]. In this case, slowing the kinetic absorption process of colloidal gold particles is induced by the decrease of electrostatic interaction between DNA-colloidal gold nanoparticles and gold surface. Therefore, a supposition about DNA condensation induced by colloidal gold is done.

DNA condensation effect is a unique phenomenon that causes DNA molecule to condense into tightly packed structures (e.g. torus, rodes, etc.), and its volume decreases by about $10^{4}$ times. It is known that ions and polyvalent 


\section{G.I. Dovbeshko et al.: Gold and colloidal gold surface influence on DNA conformational changes}
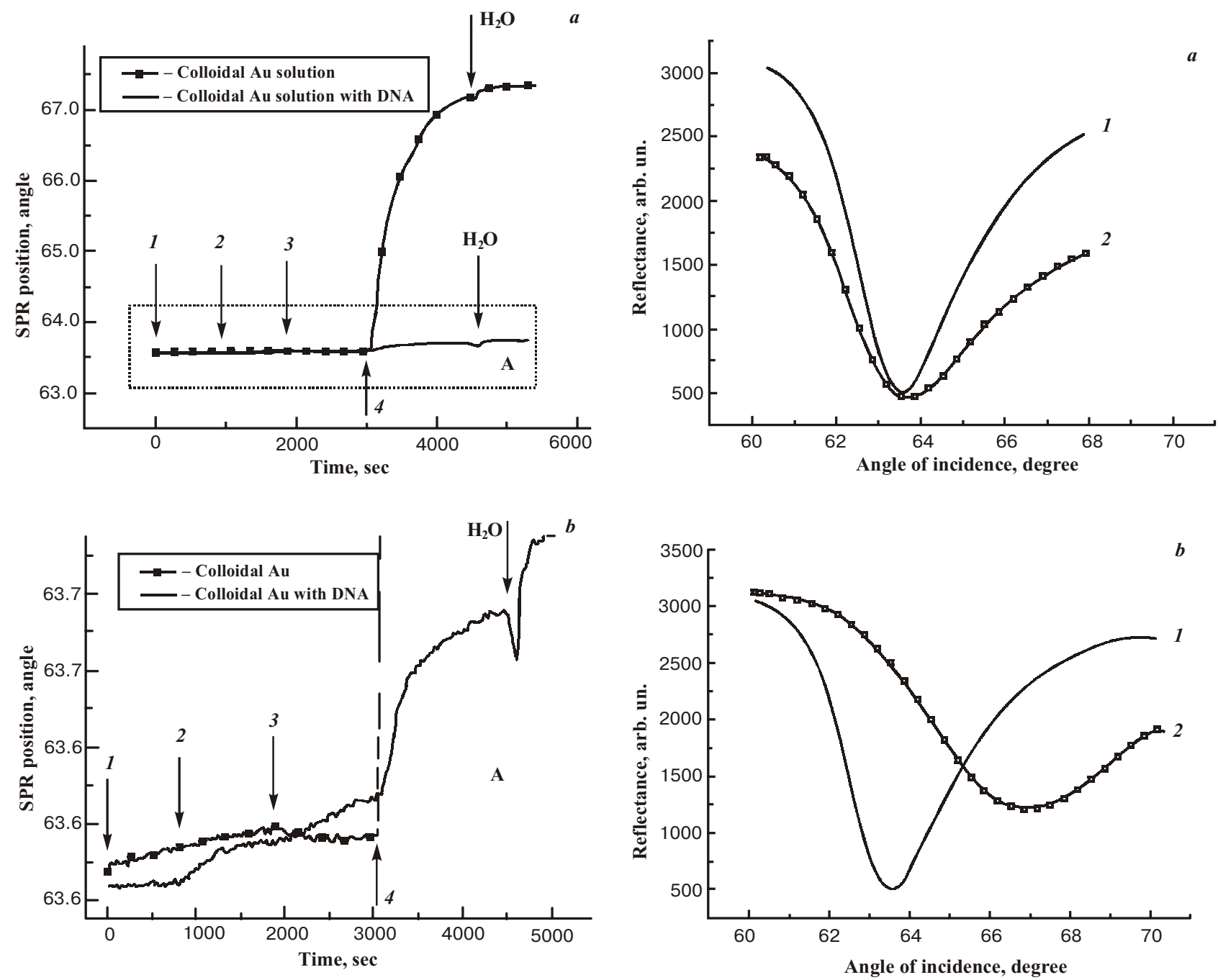

Fig. 7. $a$ - kinetic dependence of the SPR angle position for adsorption of colloidal gold (aqueous solution of $12.1 \mathrm{~g} / \mathrm{l}$ concentration) (1) and for the mixture of colloidal gold (the same concentration) with DNA (2); $b$ - the same in Y scaled form. 1 , $2,3,4$ - the points that correspond to aqueous dilution of $1 \mathrm{~g} / \mathrm{l}$ DNA aqueous solution in 1000,100, 10 and 1 of $12.1 \mathrm{~g} / \mathrm{l}$ initial colloidal gold concentration.

cations could lead to the process of condensation. Counterion condensation occurs when the distance between charges (b) in DNA is small enough for the dimensionless ratio $\lambda_{B} / b=\xi$ to exceed unity $\left(\lambda_{B}-\right.$ Bjerrum length). It is known that $\mathrm{Cr}^{3+}$ causes DNA condensation and could lead to partial DNA transition into Z-form $[30,31]$. We suppose that the effect that we observed seems to look like the process of condensation that occurs in biological systems and which is registered in vitro in DNA under the influence of inorganic and organic polycations. However, it is more interesting that, if in our case we observe the features of the condensation process, this process takes place in the system with neutral particles or charged double layer with predominant of COO-groups, namely negative ions (see Fig. 4, curve 3 with spectra of colloidal gold).

Fig. 8. $a$ - SPR curves for bare gold (I) and after adsorption of colloidal gold (aqueous solution with the concentration of $12.1 \mathrm{~g} / \mathrm{l}$ ) (2); $b$ - SPR curves for bare gold (1) and after adsorption of mixture of colloidal gold (the same concentration) with DNA (2).

According to the spectroscopic data and the principal component analysis, the structure of DNA-colloidal gold is not A or B form. However, this DNA-colloidal goldinduced form is close to B-form and has features of A and $\mathrm{Z}$-form. This data is in accordance with the earlier obtained data for DNA conformation in buffer solution induced by polyions [28, 37]. Experiments on DNA condensation by multivalent cations show the modified Bform in most cases. Divalent transition metal causes deviation from the canonical B-form in the backbone and base vibrations [29-33, 36]. Essential change in DNA conformation has been registered by trivalent cations such as $\mathrm{Eu}, \mathrm{La}, \mathrm{Tb}$, as well as cobalt hexamine and cobalt pentamine $[34,35]$. A partial conversion of the B-DNA form into Z-DNA form has been observed in some abovementioned cases [35, 37]. In our experiment, the DNA conformation induced by colloidal gold has 


\section{G.I. Dovbeshko et al.: Gold and colloidal gold surface influence on DNA conformational changes}

showed the features of A and B-form with some amount of Z-conformation and its spectroscopic features are close to condensed DNA.

\section{Conclusions}

Gold substrate does not practically influence the macromolecular conformations of DNA in contrast to colloidal gold. Colloidal gold interacts with DNA and this process seems to be similar to DNA condensation that induces DNA conformation with major BZ contribution.

\section{Acknowledgements}

We are greatly indebted to the Foundation of Fundamental Research of Ministry of Sciences and Education of Ukraine and the special programme of Academy of Sciences of Ukraine No ВЦ - 99.404/44 for financial assistance.

\section{References}

1. G. Kalyuzhny, M. Schneeweiss, A. Shanzer, A. Vaskevich, I. Rubinstein // Am. Chem. Soc., 123, pp. 3177-3178 (2001).

2. M. Stelzle, G. Weissmuller, E. Sackmann // J. Phys. Chem. 97, pp. 2974-2981 (1993)

3. L.A. Lyon, D.J. Pena, M.J. Natan, // J. Phys. Chem. 103, pp. 5826-5831 (1999).

4. B. Dubertret, M. Calame, A. Libchaber // Nature Biotechnology, 19, pp. 365-370 (2001).

5. V.I Emelyanov, N.I. Koroteev // Uspehi fizycheskikh nauk, 135(2), pp. 125-139 (1981).

6. K. Kneipp, A. Haka, H. Kneipp, K. Badizadegan, N. Yoshizawa, C. Boone, K.E. Shafer-Peltier, J.T. Motz, R.R. Dasari, M.S. Feld // Appl. Spectrosc., 56, pp. 150-154. (2002).

7. Osawa M. Handbook of Vibrational Spectroscopy; Wiley: Chichester. (2002), pp. 785-799.

8. V. A. Kosobukin // Surface. Phys., Chem., Mech., 12, pp. 520 (1983) (in Russian).

9. M. Purcell, H. Neault, H. Malonga, H. Arakawa, R. Carpentier, H.A Tajmir-Riahi // Biochim. Biophys. Acta., 1548, pp. 129-138 (2001).

10. G.I. Dovbeshko, V.I. Chegel, N.Y.Gridina, O.P. Repnytska, Y.M. Shirshov, V.P. Tryndiak, I.M.Todor, // Semiconductor Physics, Quantum Electronics and Optoelectronics., 4, pp. 202206 (2001).

11. G.I. Dovbeshko, V.I. Chegel, N.Y. Gridina, O.P. Repnytska, Y.M. Shirshov, V.P. Tryndiak, I.M. Todor, G.I. Solyanik, Biospectroscopy, 67, pp. 470-486 (2002).

12. C. Kuhne, G. Steiner, W.B. Fischer, R. Salzer // Fresenius J. Anal. Chem., 360, pp. 750-754 (1998).
13. J.A. Taboury, J. Liquier, E. Taillandier // Can.J.Chem. 63 , pp. 1909-1904 (1985).

14. E. Taillandier, J. Liquier, and J.A. Taboury, Advances in Infrared and Raman Spectroscopy, pp. 65-114 (1985).

15. H.A. Tajmir-Riahi, J.F. Neault, and M. Naoui // FEBS Letters, 370, pp. 105-108 (1995).

16. R. Schrader, Infrared and Raman Spectroscopy. Weinheim, New-York, Basel, Cambridge, Tokyo (1995).

17. F.S. Parker, Biochemical application of Raman and resonance Raman spectroscopies. Academic Press: New York, London (1983).

18. G.S. Litvinov // Biopolimers and cells, 7, pp. 32-47 (1991).

19. M. Shie, Proc. Japanese-United States Congress of Pharmaceutical Sciences. Honolulu (Hawaii). Presented in Pushchino, Moscow, Institute of Biophysics, AN USSR (1977).

20. O.P. Repnytska, G.I Dovbeshko, V.P. Tryndiak, I.M. Todor, D.V. Kosenkov // Faraday Discuss, 126, pp. 61-76 (2003).

21. W. Saenger, Principles of nucleic acid structure. Mir: Moscow (1989).

22. A.K. Boal, and V.M. Rotello // Langmiu, 16, pp. 9527-9532 (2000).

23. Yu.P. Blagoi, C.V. Kornilova, V.C. Leont'ev // Biophysics, 39, pp. 637-644 (1994)

24. M.A Semenov, T.V. Bol'buh, A.A. Krasnitskaya, V.Ya. Maleev // Radiation, Biology, Radioekology, 34, pp. 328-335 (1994).

25. P. Gaigeot, N. Leulliot, M. Ghomi, H. Jobic, C. Coulombeau, O. Bouloussa // Chemical Physics, 261, pp. 217-237 (2000).

26. G.I. Dovbeshko, O.P. Repnytska, V.P. Tryndyak, I.M. Todor, G.I. Solyanik, V.F. Chehun. In the book: Frontiers of Multifunctional Nanosystems. Kluwer Academic Publishers: Amsterdam, pp. 265-280 (2002).

27. P. Lasch, A. Pacifico, M. Diem // Biopolymers (Biospectroscopy), 67, pp. 335-338 (2002).

28. M. Diem, L. Chiriboga, P. Lasch, A. Pacifico // Biopolymers (Biospectroscopy), 67, pp. 349-353 (2002).

29. V.V. Andrushchenko, S.V. Kornilova, L.Ye. Kapinos, E.V. Hackl, V.L. Galkin, D.N. Grigoriev, Yu.P. Blagoi, // J. Mol. Struct. 408/409, pp. 225-228 (1997).

30. V.A. Bloomfield // Current Opinion in Structural Biolog. 6, pp. $334-341$ (1996).

31. V.A. Bloomfield // Biopolymers / Nucleic Acid Sci., 44, pp. 269282 (1998).

33. H.A. Tajmir-Riahi, M. Naoui, R. Ahmad // Biopolymers, 33, pp. 1819-1827 (1993).

34. H.A. Tajmir-Riahi, R. Ahmad, M. Naoui, // J. Biomol. Struct. Dyn., 10, pp. 865-877 (1993).

35. H.A Tajmir-Riahi, M. Naoui, R. Ahmad // J. Biomol. Struct. Dyn., 11, pp. 83-93 (1993).

36. J. Duguid, V.A. Bloomfield, J. Benevides, G.I. Thomas // Biophys. J., 65, pp. 1916-1928 (1993).

37. T.J. Tomas, Biochem.J. 298, pp. 485-491 (1994).

38. M. Ghomi, R. Letellier, J. Liquier, E. Taillandier // Int. J. Biochem., 22, pp. 691-699 (1990).

39. W. Pohle, H. Fritzche // Nucleic Asids Res., 8, pp. 2527-2535 (1980).

40. J.F. Baret, G.P. Carbone, P. Penon // Biopolimers, 17, pp. 23192339 (1978). 